\title{
INDUSTRIALIZATION AND TRANSPORT IN INDONESIA ON ENVIRONMENTAL DEGRADATION
}

\author{
Galih Ramadhan Febrianto \\ galihrf50@gmail.com \\ Hastarini Dwi Atmanti \\ Diponegoro University \\ J1. Prof. Sudarto No.13, Tembalang, Semarang, Jawa Tengah 50275
}

received: 21/1/20; revised: 30/11/20; approved: 14/12/20

\begin{abstract}
Economic development in a country is indicated by an increase in the number of industrial sectors and other supporting facilities such as transportation. However, there is another impact on developments inndustrial sectors and transportation, especially environmental degradation. Air pollution is one of the environmental degradation. This research was conducted to determine the short-term and long-term environmental impact of industry and transport in Indonesia. The data analysis method in this research used Autoregressive Distribution Lag (ARDL) to see the shortterm and long-term effects between research variables. The data used are data on CO2 emissions, the amount of industries and transport in Indonesia from 1965 - 2018. The results showed that the industry had a negative impact on increasing CO2 emissions in the short and long term. Meanwhile, transportation has a positive impact in the short term and a negative impact in the long term.
\end{abstract}

Keywords: economic development; transportation; industry; environmental degradation; $A R D L$

\section{INTRODUCTION}

Economic sector development is an important thing that must be carried out in a sustainable manner by a country (Helda et al., 2018). In the industrial sector, economic development can be characterized by the development (Robiani, 2005). The existence of the industrial sectors in Indonesia encourages an acceleration of economic growth, since the industrial sector can provide employment and generate changes in people's social life (Nurkolis, 2015). However, there is another impact on the development of the industrial sector, that is an occurrence of environmental degradation, because the industrial sector can produce toxic materials that can pollute the environment (Supraptini, 2002).

Zuhri (2014) argues that air pollution is one type of environmental degradation. Air pollution is indicated by carbon dioxide ( $\mathrm{CO} 2)$ emissions, which mostly come from industry, household activities and the transport sector (Gupito \& Kodoatie, 2012).

Mikayilov et al., (2017) argued that transportation or vehicles are used as a means of supporting economic activity that is created to support economic growth in developing countries. However, the growing amount of transports actually has an impact on environmental degradation. The occurrence of environmental degradation is caused by air pollution that comes from transportation fuel energy (Abouie-Mehrizi et al., 2012). In reality, economic activity must be able to operate at the same time as the environment to create an ecological balance, but both are contradictory (Helda et al., 2018).

Economic developments could happen as a result of an increment in the amount of industrial and transport sectors. On the other side, the increase in the industrial and transport sectors is related to an increase in $\mathrm{CO} 2$ emissions, which is a sign of environmental degradation. Figure 1 shows that the increase in $\mathrm{CO} 2$ gas emissions has the same trend as the increase in sectors industrial and transport in Indonesia.

Based on data from Menlhk (2018), it is reported that $46 \%$ of the main sector that is the key to producing $\mathrm{CO} 2$ emissions comes from energy used in the industrial sector, and $15 \%$ comes from the activities of the manufacturing and construction industries. This is in line with the data obtained from the press release of the Institute for Essential Services Reform on 29 March 2020 , which says that transport also has a substantial contribution to the increase in $\mathrm{CO} 2$ emissions in Indonesia. Which is $30 \%$ of total $\mathrm{CO} 2$ emissions, with the highest emissions come mainly from transport, land, which contributes as much as $88 \%$ of total emissions in this sector. This trend is predicted to rise. The transport and industrial sectors will continue to be one of the major emitters in Indonesia (IESR, 2020). 
Low-income countries that are at the stage of their economic development tend to undergo environmental degradation, but when they achieve high levels of income, there will be a turning point that reduces the impact of environmental degradationThis can be seen from the EKC curve at an early stage (pre-industrial economics) and then in the second stage (industrial economics) indicated by an economic transition from the agricultural sector to the industrial sector accompained by an increase in environmental degradation. And in the third stage (post-industrial economy), the industrial sector changes to the service sector. This movement is accompanied by a reduction in environmental pollution and an increase in state income (Panayotou, 2003).

The empirical literature on the impact of industrial and transport industries on environmental degradation, which results from $\mathrm{CO} 2$ emissions, yields different results. For example, Helda et al. (2018) analyzed the impact of GDP growth in the industrial sector, GDP growth in the transport sector and urbanization on environmental pollution in Indonesia using the Autoregressive Distributed Lags (ARDL) approach. The results of his research show that in the long run, GDP growth in the industrial and transportation sectors is positive and affects environmental pollution in Indonesia.

The research by Mikayilov et al. (2017) also says that Saudi Arabia's car transport has a negative impact on the occurrence of environmental degradation identified by an increase in $\mathrm{CO} 2$ gas in Azerbaijan. In their research, Gupito \& Kodoatie (2012) analyzed the impact of sectoral GDP in Central Java on CO2 emissions using the 2009-2010 OLS method. The results of his research show that the sector's GDP has a positive effect, while the industrial sector has a negative impact on $\mathrm{CO} 2$ emissions.

Based on the phenomena described in the paragraph above and supported by previous research, it can be concluded that economic growth marked by growth in the industrial and transportation sectors has various impacts on environmental and economic degradation. Therefore, researchers want to know more about how the short and long term effects of the industrial and transportation sectors on environmental degradation in Indonesia.

\section{METHOD}

The data source used for this research is secondary data. The secondary data was collected through the BP Statistical Review of World Energy, the Central Bureau of Statistics (BPS) and the World Bank website, as well as some of the literature on this research. The type of data used consists of an annual time series from 1965 to 2018, which include data on the number of industries, data on the amount of transport and data on carbon dioxide $(\mathrm{CO} 2)$ emissions, and the control variable is GDP and population.
The dependent variable used in this research is carbon dioxide (CO2) emissions, which are a proxy of environmental degradation. While the independent variables used are transportation and industry. The variables transportation are the amount of motor vehicles in Indonesia. The variables industry uses a proxy for the amount of industries consisting of the manufacturing, construction and mining industries in Indonesia.

Analysis of the research model using a quantitative approach using the time series dynamic analysis system with Autoregressive Distributed Lag (ARDL) model. This method was introduced by Pesaran et al., (2001). ARDL is a regression model that produces different responses to short-term relation from a dependent variable to a single unit transformation in the explanatory value (Gujarati, 2003).

The ARDL method has advantages over the cointegration techniques suggested by Engle \& Granger (1987), Johansen \& Juselius (1990) and Johansen (1988). The co-integration method introduced by Engle \& Granger (1987) with regard to long-term effects requires that all variables be stationary at the same level, while the ARDL method uses one reduced form equation and that not all variables need to be stationary at the same level, so that the variables with integration I (0) and I (1) can be used, but the stationary level should not exceed diff 2 or I(2). In addition, the ARDL method can be used for small and limited data (Pesaran et al 2001; Ali et al., 2017).

The model of the ARDL equation is stated as follows:

$$
\begin{aligned}
\Delta \mathrm{Y}_{\mathrm{t}}= & \beta_{0}+\sum_{\mathrm{i}=1}^{\mathrm{k}} \beta_{11} \Delta \mathrm{Y} 1_{\mathrm{t}-1}+\sum_{\mathrm{i}=1}^{\mathrm{k}} \beta_{22} \Delta \mathrm{X} 1_{\mathrm{t}-\mathrm{i}}+\sum_{\mathrm{i}=1}^{\mathrm{k}} \beta_{3} \\
& { }_{3} \Delta \mathrm{X} 2_{\mathrm{t}-\mathrm{i}}+\theta_{1} \mathrm{Y}_{\mathrm{t}-\mathrm{I}}+\theta_{2} \mathrm{X} 1_{\mathrm{t}-\mathrm{I}}+\theta_{3} \mathrm{X} 2_{\mathrm{t}-\mathrm{I}}+\mathrm{e}_{\mathrm{t}} \ldots \ldots \ldots(1)
\end{aligned}
$$

Where:

$\beta_{0}=$ constant

$\beta_{1} \beta_{2} \beta_{3}=$ short term coefficient

$\Delta \quad=$ first difference

$\theta_{1} \theta_{2} \theta_{3} \quad=$ long term coefficent

$\mathrm{k} \quad=$ lag length

I $\quad=$ lag sequence

$\mathrm{e}_{\mathrm{t}} \quad=$ error term

The ARDL specification refers to the model by Ali et al. (2017) and Helda et al (2018). The two studies used the ARDL model to analyze the variables tested. In this research the researcher included the $\mathrm{CO} 2$ emission variable as a dependent variable and the amount of industry and transport variables as independent variables and the GDP and population variables as control variables, so the researcher formulated the following model:

$\Delta \mathrm{CO} 2_{\mathrm{t}}=\beta_{0}+\sum_{\mathrm{i}=1}^{\mathrm{k}} \beta_{11} \Delta \mathrm{CO} 2_{\mathrm{t}-\mathrm{i}}+\sum_{\mathrm{i}=1}^{\mathrm{k}} \beta_{22} \Delta$ Industri $_{\mathrm{t}-\mathrm{i}}$ $+\sum_{\mathrm{i}=1}^{\mathrm{k}} \beta_{33} \Delta$ Transport $_{\mathrm{t}-\mathrm{i}}+\theta_{1} \mathrm{CO}_{\mathrm{t}-\mathrm{I}}+\theta_{2}$ Indust $_{\mathrm{t}-\mathrm{I}}+\theta_{3}$ Trans $_{\mathrm{t}-\mathrm{I}}+\theta_{4} \mathrm{PDB}_{\mathrm{t}-\mathrm{I}}+\theta_{5}$ Pop $_{\mathrm{t}-\mathrm{I}}+\mathrm{e}_{\mathrm{t}} \ldots \ldots \ldots \ldots \ldots \ldots \ldots$ (2) 
$\mathrm{CO} 2_{\mathrm{t}-\mathrm{i}}=\mathrm{CO} 2$ gas lag in a million tonnes, Indust $_{\mathrm{t}-\mathrm{i}}=$ Industry lag in unit quantities and $\operatorname{Trans}_{\mathrm{t}-\mathrm{I}}=$ transportation lag in unit quantities. $\mathrm{PDB}_{\mathrm{t}-\mathrm{I}}=\mathrm{Lag}$ of gross domestic product in units of rupiah. $\mathrm{PDB}_{\mathrm{t}-\mathrm{I}}=\mathrm{a}$ lag of a million per unit of the total population.

The long-term impact of this research can be written as follows:

$\theta_{1} \mathrm{CO}_{\mathrm{t}-\mathrm{I}}+\theta_{2}$ Indust $_{\mathrm{t}-\mathrm{I}}+\theta_{3}$ Trans $_{\mathrm{t}-\mathrm{I}}+\theta_{4} \mathrm{PDB}_{\mathrm{t}-\mathrm{I}}+\theta_{5}$ Pop $_{\mathrm{t}-\mathrm{I}}$

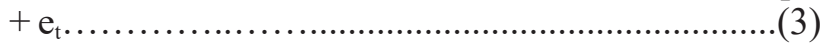

And the short-term impact can be written as follows:

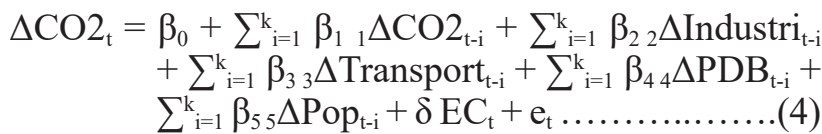

$\delta$ is the Error Correction Term (ECt) coefficient, which indicates the speed of adjustment from short-term to long-term balance. This indicates that the imbalance impacted by the previous year's shocks will be corrected to the long-term balance this year. As said by Helda et al., (2018) in order for the corrected model (ECM) to be a reliable model, the co-integrated variables must have a negative and significant relevant ECT value.

\section{RESULTS}

The initial stage of the ARDL model is to test the level of stationary of the data. This is done to make sure the data shouldn't be stationary at diff 2 to avoid fake regression (Keho, 2015). As said by Pesaran et al. (2001), the ARDL model at the stationary test level only applies when the variables are at the level and the diff 1. In this research, the stationariy test that used was the Phillips Perron approach (Table 1).

Based on the test results, it was found that the log industry (indust), $\log$ transport (trans) and $\log \mathrm{CO} 2$ $(\mathrm{CO} 2)$ emission variables were stationary at the level and diff 1 at the level of 1-5 percent. Based on the results of this stationary test, it can be concluded that the variables have been integrated in different orders, including at level and diff 1 and haven't reached the diff level, while the control variables, that is GDP and population, are also stationary at a level and diff 1 so that they fulfill the requirements of using the ADRL model.

After identifying a suitable method in this analysis, which is the ARDL model, the next step that must be taken is to determine the optimal lag length. The optimal lag test is required to explain how long the impact of one variable had on other variables.

The determination of lag period is based on the highest amount of stars in the Akaike Information Criteria (AIC), the Sequentially Updated LR Test Statistics (LR), the Final Prediction Error (FPE) and the Hannan-Quinn Information Criteria. The test results show that the optimal lag length is 4 (Table 2).
The co-integration test was carried out to see the long-term balance between the research variables. The co-integration test used in this analysis is the Cointegration Bound Test. The results show that the statistical $F$ value (4.60) is greater than the critical upper limit of $10 \%$ (3.35). Therefore, the null hypothesis that says that there is no co-integration is rejected and the alternative hypothesis accepted, which means that there is a stable long-term co-integration, relation between $\mathrm{CO} 2$ gas variables, industry and transport, as well as the control variable of GDP and population (Table 3).

The next step is to estimate the ARDL model after it is identified that there is co-integration or long-term equilibrium. Model selection based on the Akaike Information Criteria indicates the best ARDL model (1.4.1.3.2). The estimation results indicate that each variable experienced dynamic shifts from the current time to the lag 4. Similarly, the relatively high R-square and Adj R-square values, respectively 0.999264 and 0.999005 , R-square values of 0.999264 imply that 99.92 percent of the variance in the dependent $\mathrm{CO} 2$ variable can be explained by the independent variables in the analysis. This indicates that the model is good enough to be analyzed (Table 4).

The estimation results of the short-term analysis in the ARDL model which can be seen from the Error Correction Method (ECM) estimation, indicate that industrial variables have a negative impact while transport variables have a positive impact on $\mathrm{CO} 2$ gas constriction in Indonesia. The estimation results of the ECM-ARDL model also indicate that the results obtained by the ECT coefficient are negative and significant at the $1 \%$ level, which is -0.210959 . This means the ECM model used is valid. The ECT coefficient means that the adjustment process for shortterm variations occurs quite slowly. This adjustment is just about $2.1 \%$ per year. As well as the speed of adjustment from the previous period's disequilibrium to its long-term balance in the current period (Table 5).

Long-term impact of variables in the industrial and transport sectors on the increase in $\mathrm{CO} 2$ emissions. The analysis found that the industrial sector has a negative impact, which means that in the long term, the industrial world will potentially reduce the environmental degradation by $\mathrm{CO} 2$ emission. These results are also the same as with the transport variable, which indicates that there'll be less environmental degradation in the long term as the amount of transport increases (Table 6).

The classical assumption test is made in order to show good results of analysis and have a significant correlation. This test relates to the assumptions of classical linear regression models such as normality, autocorrelation and heteroscedasticity. The results of the classical assumption test indicate that this analysis passes the three criteria of the classical assumption test. It also can be assumed that the data is normally distributed, the serial is not correlated and the residuals are homoscedastic. 
The purpose of the stability test is to verify the stability of long-term measurements and short-term adjustments in the ECM-ARDL model. If the CUSUM and CUSUMSQ statistical plots are at a 5 percent significance level within the critical limits, then the null hypothesis is stable for all regression coefficients. The CUSUM and CUSUMSQ figures show that the CUSUM and CUSUMSQ plots are within the critical 5 percent limit which indicates the stability of the short-term coefficient and the long-term coefficient in ECM-ARDL (Figure 2).

\section{DISCUSSIONS}

Based on Tables 5 and 6 , it can be concluded that the industry has a negative impact on increasing $\mathrm{CO} 2$ gas emissions in the short term. The negative impact of the industry in the short-term means that an increase in the number of industrial sectors in the short-term doesn't have a significant impact on environmental degradation, as an increment in the amount of industries in Indonesia is accompanied by an industry environmental concern and is supported by government programs such as AMDAL.

Based on data from the website http://ppid.menlhk. go.id/ which says that the government's attempts to regulate and prevent it by making efforts to control compliance with the standardization of pollution of raw materials in the industrial sector, which then takes out routine and integrated emission reporting. This is achieved through a reporting system at the Ministry of Environment and Forestry and is also supported by a network of air quality monitoring systems or e-quality monitoring systems in 26 cities all over Indonesia. The monitoring and prevention process can also be conducted out in the short term.

However, in the long term, the increase in the number of these industries in terms of quantity is not balanced with their contribution to economic development, which can lead to a continuous increase in $\mathrm{CO} 2$ emissions. The results of this study are consistent with the results of the research that conducted by Helda et al. (2018) which examined the impact of the GDP, industrial sector on $\mathrm{CO} 2$ emissions in Indonesia and found that the industrial sector has a positive in long-term impact.

This result is also consistent with research conducted by Hutabarat et al. (2010) on the effects of GDP on environmental quality in the industrial sector in 5 ASEAN countries. The results of his research revealed that at an early stage, sulfur and $\mathrm{CO} 2$ emissions had increased and increased significantly to a turning point occurred which had a positive impact on $\mathrm{CO} 2$ emissions, but didn't last too long, so that the growth of the industrial sector would have a much more negative impact on the environment in the long term.

Different with the industrial sector, which has a positive impact on environmental degradation in the short term and a negative impact in the long term, both transports in the short and long term has a negative impact on the increase in $\mathrm{CO} 2$ emissions. The results of this research are consistent with the research carried out by Tobing (2013), which also suggests that motor vehicles or transport can have an impact on the quality of $\mathrm{CO} 2$ emissions in the air. This impact is based on the fact that at the beginning of economic development, a country, usually develops infrastructure which can relate to an increment in the amount of transports and have a negative impact on the environment. Then, along with the rise in the amount of motor vehicles and not supported by the use of environmentally friendly fuels, it's actually an increase in the amount of $\mathrm{CO} 2$ emissions in Indonesia.

\section{CONCLUSIONS}

The conclusion of this analysis is that there is a short-term and long-term relation between the variables of research. Industrial variables have a positive impact on environmental degradation in the short term and a negative impact on environmental degradation in the long term. Meanwhile the transport variable has a negative impact on environmental degradation in the short and long term.

The government needs to pay attention to the level of contribution made by the industrial sector to the economy, as well as to monitor intensively the disposal of waste and chimneys that are well managed to support economic growth that goes hand in hand with a healthy environment in the long term. The Government also needs to make innovations that related to environmentally friendly fuels so that the increase in the number of vehicles would not have a significant impact on the increase in environmental degradation.

The government and community must implement and continue promoting for green economic policies through innovation and environmentally friendly production in all economic activities, with the purpose of avoiding excessive use of energy and support the reduction of environmental degradation.

\section{REFERENCES}

Abouie-Mehrizi, M., Atashi, S. M., \& Elahi, M. 2012. The effect of variables population growth, urbanization and economic growth on CO2 Emissions in Iran. African Journal of Business Management, 6(28), 8414-8419.

Ali, H. S., Abdul-Rahim, A., \& Ribadu, M. B. 2017. Urbanization and carbon dioxide emissions in Singapore: evidence from the ARDL approach. Environmental Science and Pollution Research, 24(2), 1967-1974.

Engle, R. F., \& Granger, C. W. 1987. Co-integration and error correction: representation, estimation, and testing. Econometrica: journal of the Econometric 
Society, 251-276.

Gupito, K. R., \& Kodoatie, J. M. 2012. Keterkaitan PDRB Perkapita Dari Sektor Industri, Transportasi, Pertanian dan Kehutanan Terhadap Kualitas Lingkungan Diukur Dari Emisi Coz (Studi kasus di: 30 Kab/Kota Provinsi Jawa Tengah Tahun 20092010). Fakultas Ekonomika dan Bisnis.

Helda, N. P., Jamal, A., \& Dawood, T. C. 2018. Pengaruh urbanisasi, pertumbuhan PDB sektor industri dan PDB sektor transportaso terhadap polusi lingkungan di Indonesia. Jurnal Ekonomi dan Kebijakan Publik Indonesia, 5(2), 168-183.

Hutabarat, L., \& Sugiyanto, F. 2010. Pengaruh PDB sektor industri terhadap kualitas lingkungan ditinjau dari emisi sulfur dan $\mathrm{CO} 2$ di lima negara anggota ASEAN periode 1980-2000. Universitas Diponegoro.

Johansen, S. 1988. Statistical analysis of cointegration vectors. Journal of economic dynamics and control, 12(2-3), 231-254.

Johansen, S., \& Juselius, K. 1990. Maximum likelihood estimation and inference on cointegration - with applications to the demand for money. Oxford Bulletin of Economics and statistics, 52(2), 169210.

Keho, Y. 2015. An econometric study of the long-run determinants of $\mathrm{CO} 2$ emissions in cote d'ivoire. Journal of Finance and Economics, 3(2), 11-21.

Kementrian Lingkungan dan kehutanan. 2018. Inventarisasi gas rumah kaca dan monitoring, pelaporan verifikasi tahun 2018. Laporan Inventarisasi Gas Rumah Kaca dan MPV.

Mikayilov, J., Shukurov, V., Mukhtarov, S., \& Yusifov, S. 2017. Does urbanization boost pollution from transport?

Nurkolis, N. 2015. Dampak Keberadaan Industri

Table 1. Unit Roots Test Phillips Perron

\begin{tabular}{lccc}
\hline \multicolumn{1}{c}{ Variable } & PP & Critical Value & Description \\
\hline $\log (\mathrm{CO} 2)$ & -5.563186 & -3.562669 & $\mathrm{I}(1)$ \\
$\log ($ indust $)$ & -3.627341 & -3.560019 & $\mathrm{I}(0)$ \\
$\log ($ trans $)$ & -3.320527 & -2.918778 & $\mathrm{I}(1)$ \\
$\log ($ PDB $)$ & -6.372048 & -3.562669 & $\mathrm{I}(1)$ \\
$\log ($ Pop $)$ & -16.33308 & -3.560019 & $\mathrm{I}(0)$ \\
\hline
\end{tabular}

Source: Data processing results that are processed using Eviews $10(2020)$
Terhadap Kondisi Sosial Ekonomi Masyarakat Serta Lingkungan Sekitar Industri: Skripsi.

Panayotou, T. 2003. Economics Growth and the Environmental. Harvard University and Cyprus International Institute of Management.

Pesaran, M. H., Shin, Y., \& Smith, R. J. 2001. Bounds testing approaches to the analysis of level relationships. Journal of applied econometrics, 16(3), 289-326.

Robiani, B. 2005. Analisis Pengaruh Industrialisasi terhadap Pertumbuhan Ekonomi di Sumatera Selatan. Jurnal Ekonomi dan Pembangunan Indonesia, 6(1), 93-103.

Suparmoko, M. 2008. Ekonomi Sumberdaya Alam dan Lingkungan, Suatu Pendekatan Teoritis Edisi empat revisi: Yogyakarta: BPFE.

Supraptini, S. 2002. Pengaruh Limbah Industri Terhadap Lingkungan Di Indonesia. Media Penelitian dan Pengembangan Kesehatan, 12(2).

Tobing, K. R. L., \& Istirokhatun, T. 2013. Pengaruh Jumlah Kendaraan dan Faktor Meteorologis (Suhu, Kecepatan Angin) Terhadap Peningkatan Konsentrasi Gas Pencemar CO, NO2, dan SO2 Pada Persimpangan Jalan Kota Semarang (Studi Kasus Jalan Karangrejo Raya, Sukun Raya, dan Ngesrep Timur V). DIPOIPTEKS: Jurnal Ilmiah Mahasiswa Undip, 1(1), 25-28.

Transportasi darat sumbang emisi tertinggi dari total emisi gas rumah kaca sektor transportasi di Indonesia. Retrieved from http://iesr.orid/wpcontent/uploads/2020/03/Siaran-Pers-KendaraanListrik-dan-Dekarbonisasi-Sektor-TransportasiDarat-Indonesia_29_Mar_2020.pdf

Zuhri, M. S. 2014. Pengaruh Faktor-faktor Demografi Terhadap Emisi Udara di Indonesia. Jurnal Ilmu Ekonomi dan Pembangunan, 14(2).

Table 2. Optimal Lag Test Result

\begin{tabular}{ccccc}
\hline Lag & LR & FPE & AIC & HQ \\
\hline 0 & NA & $2.63 \mathrm{e}+39$ & 99.28128 & 99.32496 \\
1 & 515.7262 & $5.10 \mathrm{e}+34$ & 88.42984 & 88.60458 \\
2 & 13.62344 & $5.35 \mathrm{e}+34$ & 88.47301 & 88.77882 \\
3 & 11.76991 & $5.78 \mathrm{e}+34$ & 88.53876 & 88.97563 \\
4 & $51.87854^{*}$ & $2.08 \mathrm{e}+34^{*}$ & $87.49664^{*}$ & $88.06457^{*}$ \\
\hline
\end{tabular}

Source: Data processing results that are processed using Eviews $10(2020)$

Table 3. Cointegration Bound Test

\begin{tabular}{ccccc}
\hline F-stat & 4.607389 & $10 \%$ & 2.63 & 3.35 \\
\hline $\mathrm{k}$ & 2 & $5 \%$ & 3.1 & 3.87 \\
& & $2.50 \%$ & 3.55 & 4.38 \\
& & $1 \%$ & 4.13 & 5 \\
\hline
\end{tabular}

Source: Data processing results that are processed using Eviews $10(2020)$ 
Table 4. ARDL Model Estimation Results

\begin{tabular}{lrrrr}
\hline \multicolumn{1}{c}{ Variabel } & Coefficient & Std. Error & t-Statistic & \multicolumn{1}{c}{ Prob.* } \\
\hline LOG(CO2(-1)) & 0.093519 & 0.117806 & 0.793836 & 0.4328 \\
LOG(Indust) & 0.145809 & 0.195641 & 0.745285 & 0.4612 \\
LOG(Indust(-1)) & -0.255294 & 0.245432 & -1.040181 & 0.3056 \\
LOG(Indust(-2)) & -0.142172 & 0.242172 & -0.587072 & 0.561 \\
LOG(Indust(-3)) & -0.229114 & 0.219568 & -1.043477 & 0.3041 \\
LOG(Indust(-4)) & 0.356194 & 0.120987 & 2.944072 & 0.0058 \\
LOG(Trans) & 0.131529 & 0.126124 & 1.042853 & 0.3044 \\
LOG(Trans(-1)) & -0.576194 & 0.156398 & -3.684146 & 0.0008 \\
LOGPDB & 0.039078 & 0.100282 & 0.38968 & 0.6992 \\
LOGPDB(-1) & 0.154326 & 0.113071 & 1.364863 & 0.1813 \\
LOGPDB(-2) & 0.171822 & 0.115325 & 1.489886 & 0.1455 \\
LOGPDB(-3) & 0.231126 & 0.0991 & 2.332249 & 0.0257 \\
LOGPop & 709.1633 & 119.5709 & 5.930902 & 0.0000 \\
LOGPop(-1) & -1365.31 & 220.4602 & -6.193001 & 0.0000 \\
LOGPop(-2) & 668.57 & 104.8694 & 6.375265 & 0.0000 \\
C & -94.47065 & 17.85391 & -5.291316 & 0.0000 \\
R-squared & 0.999465 & & DW stat & 2.218316 \\
Adj R-squared & 0.999228 & & F-statistic & 4231.366 \\
\hline SOurce: Data & & &
\end{tabular}

Source: Data processing results that are processed using Eviews $10(2020)$

Table 5. Short-term estimates of the ECM Model

\begin{tabular}{lrrrl}
\hline \multicolumn{1}{c}{ Variabel } & Coefficient & \multicolumn{1}{c}{ SE } & t-Statistic & Prob. \\
\hline DLOG(Indust) & -0.356198 & 0.106003 & -3.360269 & 0.0019 \\
DLOG(Trans) & 0.131528 & 0.104499 & 1.258655 & 0.2167 \\
D(LOGPDB) & -0.402954 & 0.093803 & -4.29576 & 0.0001 \\
D(LOGPop) & 709.1733 & 94.0843 & 7.537637 & 0.0000 \\
CointEq(-1)* & -0.90649 & 0.098688 & -9.18541 & 0.0000 \\
\hline
\end{tabular}

Source: Data processing results that are processed using Eviews $10(2020)$

Table 6. Long Term Estimates

\begin{tabular}{lrcrl}
\hline \multicolumn{1}{c}{ Variabel } & Coefficient & SE & t-Statistic & Prob. \\
\hline LOG(Indust) & -0.13743 & 0.155532 & -0.883611 & 0.3831 \\
LOG(Trans) & -0.49054 & 0.070235 & -6.98425 & 0.0000 \\
LOG(PDB) & 0.657876 & 0.132064 & 4.981501 & 0.0000 \\
LOG(Pop) & 13.70476 & 1.849288 & 7.410828 & 0.0000 \\
C & -104.2169 & 12.78605 & -8.150828 & 0.0000 \\
\hline
\end{tabular}

Source: Data processing results that are processed using Eviews $10(2020)$

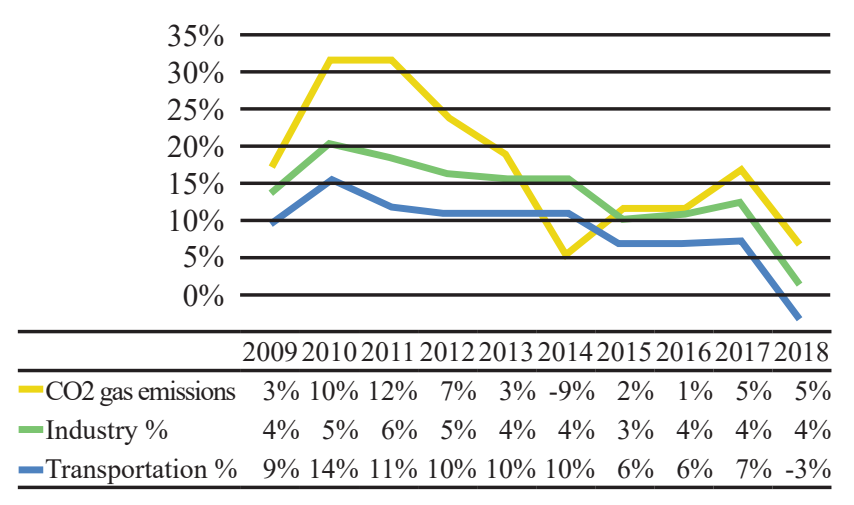

Figure 1. $\mathrm{CO}_{2}$ Emission

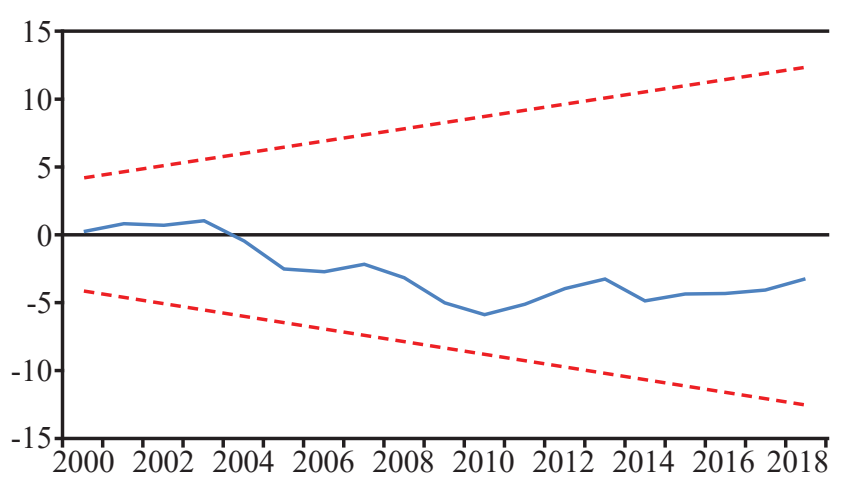

- CUSUM ---5\% Significance

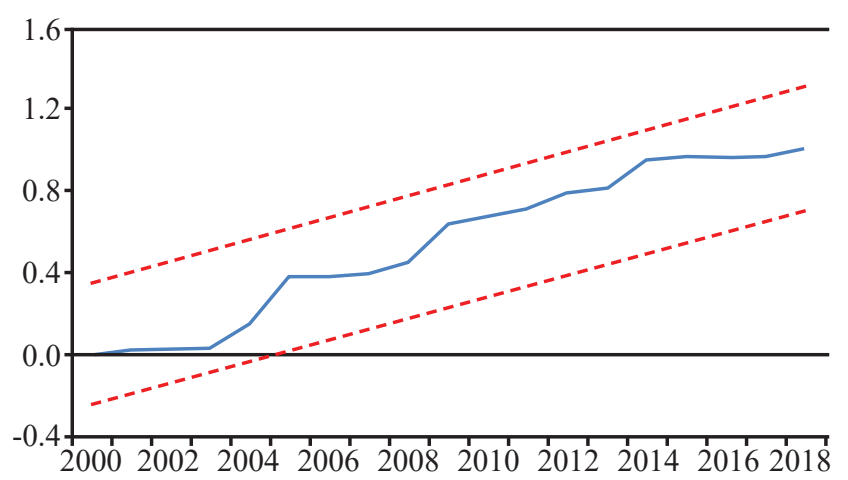

_ CUSUM of Squares -- -5\% Significance

Figure 2. Result of Cumulative Sum (CUSUM) of Recursive Residuals and Cumulative Sum of Squares (CUSUMSQ) of Recursive Residuals 